\title{
Penampilan Fenotipik Anyelir Interspesifik Hasil Persilangan Dianthus caryophyllus 'Pradorafit' x Dianthus chinensis 'SKIl_l'
}

\author{
Minangsari Dewanti ${ }^{1}$, Neni Rostini ${ }^{2}$, Murdaningsih Haeruman Karmana ${ }^{2}$ dan Anas ${ }^{2}$ \\ ${ }^{1}$ Balai Penelitian Tanaman Hias, Jl. Raya Ciherang-Pacet, Cianjur 43253 \\ 2Ilmu Pertanian, Fakultas Pertanian, Universitas Padjadjaran Bandung
}

\begin{abstract}
Phenotypic of interspecific hybridization of carnation Dianthus caryophyllus 'Pradofit' $\mathrm{x}$ Dianthus chinensis 'SKII_I'
\end{abstract}

Interspecific hybridization becomes an effective strategy in ornamental plant breeding. This technique is an important tool to create a new type of variety. The objective of this study was to get $F_{1}$ carnation hybrid which have superior performance as potted ornamental plant. The experiment was conducted at the Indonesian Ornamental Crops Research Institute experiment station in Cipanas - Cianjur, from November 2014 - July2015. The experiment was conducted with an experimental method using randomized block design (RBD). The treatment consisted of 17 $F_{1}$ genotypes of interspecific carnation. The result showed that a large part of $C$ population genotype have some characters that agree with potted carnation, i.e shorter plant, larger stem diameter, many number of branch, early flowering, longer vase life and many bloomed flower at the same time. C5. C8, C9, C10 and C12 genotype potential used as potted carnation.

Keywords: Plant breeding, Potted characteristics, Ornamental plant

\begin{abstract}
ABSTRAK
Hibridisasi interspesifik dapat menjadi strategi yang efektif dalam pemuliaan tanaman hias. Teknik ini merupakan sarana yang penting untuk menghasilkan varietas tipe baru. Penelitian ini bertujuan untuk mendapatkan hybrid $F_{1}$ anyelir yang berpenampilan unggul sebagai tanaman hias pot. Percobaan dilaksanakan di rumah serre Kebun Percobaan Penelitian Tanaman Hias CipanasCianjur, dari bulan November 2014 sampai Juli 2015. Percobaan menggunakan Rancangan Acak Kelompok. Perlakuan terdiri dari 17 genotip anyelir interspesifik. Hasil penelitian menunjukkan bahwa sebagian besar genotip populasi $\mathrm{C}$ memiliki karakter yang sesuai dengan karakter anyelir tipe pot, yaitu tanaman pendek, diameter batang besar, jumlah cabang banyak, genjah, bunga bertahan lama dan jumlah bunga mekar/waktu banyak. Genotip C5, C8, C9, C10 dan C12 potensial dijadikan anyelir tipe pot.
\end{abstract}

Kata kunci: Pemuliaan tanaman, Karakteristik tipe pot, Tanaman hias

\section{PENDAHULUAN}

Anyelir (Dianthus caryophyllus L.) merupakan salah satu komoditas bunga potong komersial yang sangat penting di dunia, selain mawar dan krisan (Tarannum \& Naik, 2014). Ketiga komoditas bunga potong ini menguasai hampir $50 \%$ pasar bunga potong dunia (Jawaharlal et al., 2010). Anyelir komersial yang ada saat ini merupakan turunan dari spesies D. caryophyllus yang berasal dari Eropa bagian selatan dan Asia bagian barat (Mii et al., 1990). Anyelir potong mulai menduduki pasar domestik tahun 1987 (Hardjoko, 1999). 
Anyelir bunga potong memiliki beberapa karakter baik, yaitu warna bunga yang sangat bervariasi, kesegaran bunga yang cukup lama, memiliki petal bunga ganda. Namun anyelir potong masih ada beberapa kekurangan, seperti siklus pertanaman yang lama atau umur berbunga lama, perlu penopang untuk tumbuh tegak, kurang tahan terhadap penyakit layu bakteri dan Fusarium, serta setek tunas lama berakar. Dianthus chinensis yang merupakan tanaman hias taman memiliki beberapa kelebihan, yaitu mudah dibudidayakan, berbunga cepat, tanaman kompak, perbanyakkan dengan setek tunas mudah dan cepat berakar, menghasilkan banyak serbuk sari, serta agak tahan terhadap penyakit utama anyelir, yaitu layu Fusarium.

Hibridisasi interspesifik dapat menjadi strategi yang efektif dalam pemuliaan tanaman hias (Kato et al., 2008). Persilangan antar spesies anyelir dengan karakter yang sangat berbeda diharapkan dapat menghasilkan turunan tipe baru dengan karakter warna dan pola warna baru atau siklus hidup yang lebih pendek (Demmink, 1978). Hibrid hasil persilangan antara anyelir dengan spesies Dianthus lain dapat menjadi sumber yang bermanfaat bagi penyediaan karakter-karakter genetik untuk mencapai tujuan program pemuliaan anyelir (Office of The Gene Technology Regulator, 2015).

Beberapa karakter yang menjadi tujuan perakitan anyelir tipe pot adalah cepat berbunga, tinggi tanaman kurang dari $50 \mathrm{~cm}$, memiliki warna bunga yang cerah dan kuat, berbunga sepanjang musim, pertumbuhan yang vigor, kompak, percabangan yang bagus, kesegaran bunga lama dan jumlah bunga banyak. Tujuan penelitian ini adalah untuk mendapatkan hybrid $F_{1}$ anyelir yang berpenampilan unggul sebagai tanaman hias pot.

\section{BAHAN DAN METODE}

Percobaan dilaksanakan di rumah serre Kebun Percobaan Penelitian Tanaman Hias Cipanas, Cianjur, Jawa Barat, dengan ketinggian $1.100 \mathrm{~m}$ dpl, dari bulan November 2014 sampai Juli 2015. Penelitian ditata dalam rancangan acak kelompok lengkap dengan 17 perlakuan dan dua ulangan. Macam perlakuan terdiri dari 17 genotip F1 hasil persilangan Dianthus caryophyllus 'Pradorafit' $\mathrm{x}$ Dianthus chinensis 'SK11_1', yaitu : C1, C2, C3, C4, C5, C7, C8, C9, C10, C11, C12, C13, C14, C15, C16, C17 dan C18.

Bahan lainnya adalah sekam bakar, humus bambu, pupuk kandang, Urea, SP36, KCl, pupuk
NPK (15:15:15), dan gandasil D. Pestisida yang digunakan yang berbahan aktif : carbofuran 3\%, mancozeb 80\%, imidakloprit $200 \mathrm{~g} / \mathrm{l}$, dikofol $191 \mathrm{~g} / 1$ dan detametrin $25 \mathrm{~g} / 1$.

Bibit anyelir interspesifik ditanam di polybag berdiameter $15 \mathrm{~cm}$ yang berisi campuran tanah, humus bambu dan pupuk kandang dengan perbandingan 2 : 2 : 1, pada dasar lubang tanam diberi carbofuran 3\% sekitar 2 g. Pemupukan dasar diberikan saat penanaman bibit dengan dosis urea 4 g/tanaman, SP36 $3 \mathrm{~g} /$ tanaman dan $\mathrm{KCl} 3 \mathrm{~g} /$ tanaman. Pada setiap polybag ditanam dua planlet. Setiap klon ditanam sebanyak lima polybag pada setiap ulangan. Pemeliharaan tanaman meliputi penyiraman, pemupukan dan pengendalian hama penyakit.

Pengamatan pada setiap ulangan dilakukan pada lima tanaman. Pengamatan dilakukan pada saat tanaman mulai berbunga, pengamatan meliputi pengamatan terhadap beberapa karakter batang, daun dan bunga, meliputi : (1) tinggi tanaman $(\mathrm{cm})$, (2) diameter batang (cm), (3) jumlah cabang, (4) panjang daun $(\mathrm{cm}),(5)$ lebar daun $(\mathrm{cm}),(6)$ umur inisiasi berbunga (hst), (7) umur bunga mekar, (8) diameter bunga (cm), (9) lama kesegaran bunga (hari), (10) jumlah bunga mekar dalam satu waktu, (11) warna batang, (12) warna daun, (13) warna petal, (14) warna putik, (15) warna anther, (16) tekstur daun, polos atau berbulu, (17) tipe bunga, standar atau spray, (18) bentuk bunga, ganda atau tunggal, (19) bentuk tepi petal, bergerigi atau rata, (20) jumlah warna petal dan (21) aroma. Pengamatan warna menggunakan color chart The Royal Horticultural Society.

Data yang diperoleh selanjutnya dianalisis dengan sidik ragam. Karakter-karakter yang berbeda nyata pada uji $\mathrm{F}$ dengan taraf 5\% selanjutnya dikelompokkan berdasarkan uji Scott-Knott pada taraf 5\%.

\section{HASIL DAN PEMBAHASAN}

Populasi C yang merupakan hasil hibridisasi antara "Pradorafit" x SK 11_1 memiliki karakter batang dan daun yang menyerupai tetua jantan, terutama karakter tekstur daun. Semua genotip C memiliki tekstur daun berbulu seperti tetua jantan. Hampir semua genotip C memiliki warna batang dan daun menyerupai tetua betina dan jantan, yaitu hijau grup, kecuali warna batang C16 yang hijau kekuningan (Tabel 1.). Gen pengendali karakter warna batang hijau kemungkinan heterosigos, Hh, sehingga ketika bersilang dengan hijau (Hh) diperoleh turunan yang sebagian besar hijau $(\mathrm{HH}$ 
dan Hh) dan hijau kekuningan (hh). Karakter tekstur daun semua hibrid yang mengikuti karakter tekstur daun tetua jantannya menunjukkan bahwa karakter ini tidak diwariskan secara sitoplasmik, sehingga gen pengendali karakter ini berada di inti. Tetua jantan dan klon-klon $F_{1}$ yang memiliki karakter tekstur daun berbulu tidak terserang kutu jingga, sebaliknya tetua betina yang berdaun polos terserang kutu ini. Hasil penelitian Indrayani \& Sumartini (2012) pada tanaman kapas menunjukkan bahwa bulu daun sebagai salah satu sifat fisik/morfologi tanaman kapas mempunyai hubungan erat dengan ketahanan terhadap Amrasca biguttula. Varietas kapas yang berbulu cenderung lebih tahan terhadap serangan hama tersebut dibandingkan dengan varietas yang tidak berbulu.

Tetua betina populasi $\mathrm{C}$ memiliki warna bunga hijau kekuningan, warna ini tidak ditemukan pada semua genotip C. Hampir semua genotip C memiliki warna bunga merah keunguan seperti tetua jantan, kecuali genotip C10 yang memiliki warna dasar bunga merah. Warna putik tetua betina, yaitu putih tidak diturunkan pada semua genotip C. Warna putik genotip $C$ beragam antara merah keunguan sampai ungu. Hal ini menunjukkan bahwa warna putik tetua jantan merah keunguan merupakan warna dominan terhadap warna putih (Tabel 2.).

Tabel 1. Karakter batang dan daun populasi C ("Pradorafit" x SK11_1).

\begin{tabular}{ccccc}
\hline Genotip & Warna Batang & Warna Daun & Tekstur Daun & Bentuk ujung daun \\
\hline Pradorafit & GG 139C & GG N 138B & Polos & Lancip \\
SK11_1 & GG 137A & GG 138A & Berbulu & Lancip \\
C1 & GG 143A & GG 137A & Berbulu & Lancip \\
C2 & GG 143A & GG 137A & Berbulu & Lancip \\
C3 & GG 143B & GG 137A & Berbulu & Lancip \\
C4 & GG 138B & GG 137A & Berbulu & Lancip \\
C5 & GG N 138B & GG 137A & Berbulu & Lancip \\
C7 & GG 137 C & GG 137A & Berbulu & Lancip \\
C8 & GG 138A & GG 137A & Berbulu & Lancip \\
C9 & GG 138 A & GG 137A & Berbulu & Lancip \\
C10 & GG 143B & GG 137A & Berbulu & Lancip \\
C11 & GG 143B & GG 143A & Berbulu & Lancip \\
C12 & GG 143B & GG 137A & Berbulu & Lancip \\
C13 & GG 138B & GG 137A & Berbulu & Lancip \\
C14 & GG 138B & GG 137A & Berbulu & Lancip \\
C15 & GG 143A & GG 137A & Berbulu & Lancip \\
C16 & YGG 147A & GG 137A & Berbulu & Lancip \\
C17 & GG 138A & GG 137A & Berbulu & Lancip \\
C18 & GG 138A & GG 137A & Berbulu & Lancip \\
\hline
\end{tabular}

Keterangan : GG = Green Group, YGG = Yellow Green Group.

Warna anther genotip $C$ sangat beragam dari putih keabuan, putih kehijauan, violet, abu, ungu keabuan. Lima genotip, yaitu genotip C7, C11, C12, C17 dan C18 memiliki warna anther menyerupai warna anther tetua jantan, yaitu hitam grup.

Genotip C10 memiliki jumlah warna petal seperti tetua betina, yaitu dua, sedangkan sebelas genotip lainnya memiliki satu warna bunga. Semua genotip C memiliki karakter tipe bunga spray seperti tetua jantan, karakter bentuk bunga ganda seperti tetua betina dan aroma bunga seperti tetua jantan.

Pengamatan morfologi genotip-genotip C menunjukkan bahwa hampir semua genotip C memiliki penampilan fenotipik yang merupakan perpaduan antara kedua tetua.

Berdasarkan penampilan tinggi tanaman, 17 genotip populasi $\mathrm{C}$ terbagi menjadi tiga kelompok dengan rentang rata-rata kelompok antara $46,76 \mathrm{~cm}$ sampai dengan $66,51 \mathrm{~cm}$ (Tabel 3.). 
Tabel 2. Karakter bunga populasi C (hasil hibridisasi "Pradorafit” x SK11_1).

\begin{tabular}{|c|c|c|c|c|c|c|c|c|}
\hline Genotip & $\begin{array}{c}\text { Warna } \\
\text { petal }\end{array}$ & Warna putik & $\begin{array}{l}\text { Warna } \\
\text { anther }\end{array}$ & $\begin{array}{c}\text { Jumlah } \\
\text { warna } \\
\text { petal }\end{array}$ & $\begin{array}{c}\text { Tipe } \\
\text { bunga }\end{array}$ & $\begin{array}{c}\text { Bentuk } \\
\text { bunga }\end{array}$ & $\begin{array}{c}\text { Bentuk } \\
\text { tepi petal }\end{array}$ & Aroma \\
\hline Pradorafit & YGG 145D & WG 155C & $\begin{array}{l}\text { WG } \\
155 A\end{array}$ & 1 & Standar & ganda & Agak rata & $\begin{array}{c}\text { Tidak } \\
\text { Ada }\end{array}$ \\
\hline SK11_1 & $\begin{array}{c}\text { RPG N } \\
67 \mathrm{~A} / \mathrm{RPG} \\
61 \mathrm{~B}\end{array}$ & $\begin{array}{l}\text { RPG 70A/ } \\
\text { WG 155C }\end{array}$ & BG 202B & 2 & spray & tunggal & Bergerigi & Ada \\
\hline C1 & RPG 63B & PG N 79C & $\begin{array}{c}\text { GPG } \\
186 B\end{array}$ & 1 & spray & ganda & Bergerigi & Ada \\
\hline $\mathrm{C} 2$ & RPG 67C & $\begin{array}{l}\text { PG 77A / } \\
\text { RPG 65A }\end{array}$ & $\begin{array}{c}\text { GPG N } \\
187 \mathrm{C}\end{array}$ & 1 & spray & ganda & Bergerigi & Ada \\
\hline C3 & RPG 61C & RPG 70A & $\begin{array}{c}\text { GWG } \\
157 \mathrm{~A}\end{array}$ & 1 & spray & ganda & Bergerigi & Ada \\
\hline $\mathrm{C} 4$ & $\begin{array}{c}\text { RPG N } \\
74 \mathrm{~B}\end{array}$ & PG N 78B & BG 202B & 1 & spray & ganda & Bergerigi & Ada \\
\hline C5 & RPG 67B & RPG N 74C & $\begin{array}{c}\text { GPG N } \\
187 \mathrm{C}\end{array}$ & 1 & spray & ganda & Bergerigi & Ada \\
\hline $\mathrm{C} 7$ & $\begin{array}{c}\text { RPG N } \\
66 \mathrm{~B}\end{array}$ & RPG 71A & BG 202B & 1 & spray & ganda & Bergerigi & Ada \\
\hline $\mathrm{C} 8$ & RPG 68A & RPG 71A & $\begin{array}{c}\text { GPG N } \\
187 \mathrm{C}\end{array}$ & 1 & spray & ganda & Bergerigi & Ada \\
\hline $\mathrm{C} 9$ & $\begin{array}{c}\text { RPG N } \\
57 A \\
\text { RG 53B }\end{array}$ & RPG 71A & $\begin{array}{c}\text { GPG N } \\
187 \mathrm{~B}\end{array}$ & 1 & spray & ganda & Bergerigi & Ada \\
\hline $\mathrm{C} 10$ & $\begin{array}{c}\text { RPG N } \\
57 \mathrm{~B}\end{array}$ & RPG 64B & GG 201B & 2 & spray & ganda & Bergerigi & Ada \\
\hline $\mathrm{C} 11$ & $\begin{array}{c}\text { RPG N } \\
74 \mathrm{~B}\end{array}$ & PVG N 81A & BG 202B & 1 & spray & ganda & Bergerigi & Ada \\
\hline $\mathrm{C} 12$ & $\begin{array}{c}\text { RPG N } \\
74 \mathrm{~A}\end{array}$ & PG 75A & BG 202B & 1 & spray & ganda & Bergerigi & Ada \\
\hline $\mathrm{C} 13$ & $\begin{array}{c}\text { RPG N } \\
57 \mathrm{~A}\end{array}$ & RPG 59A & $\begin{array}{c}\text { WG } \\
155 A\end{array}$ & 1 & spray & ganda & Bergerigi & Ada \\
\hline $\mathrm{C} 14$ & $\begin{array}{c}\text { RPG N } \\
60 \mathrm{~A}\end{array}$ & RPG 72B & VG 84B & 1 & spray & ganda & Bergerigi & Ada \\
\hline C15 & $\begin{array}{c}\text { RPG N } \\
74 \mathrm{~A}\end{array}$ & PG N 78B & - & 1 & spray & ganda & Bergerigi & Ada \\
\hline $\mathrm{C} 16$ & $\begin{array}{c}\text { RPG N } \\
74 \mathrm{~A}\end{array}$ & PG 75A & $\begin{array}{c}\text { GWG } \\
156 \mathrm{~B}\end{array}$ & 1 & spray & ganda & Bergerigi & Ada \\
\hline $\mathrm{C} 17$ & $\begin{array}{c}\text { RPG N } \\
74 \mathrm{~B}\end{array}$ & PG N 78A & BG 202B & 1 & spray & ganda & Bergerigi & Ada \\
\hline $\mathrm{C} 18$ & $\begin{array}{c}\text { RPG N } \\
74 \mathrm{~A}\end{array}$ & PG 77B & BG 202B & 1 & spray & ganda & Bergerigi & Ada \\
\hline
\end{tabular}

Keterangan : RG = Red Group, PVG = Purple Violet Group, GG = Grey Group, RPG = Red Purple Group, GWG $157=$ Green White Group, VG = Violet Group, PG = Purple Group, GWG $156=$ Greyed White Group, WG = White Group, GPG = Greyed Purple Group, BG = Black Group, YGG = Yellow Green Group

Penampilan rata-rata diameter batang Kelompok I terdiri dari dua genotip. Kelompok II terbagi menjadi tiga kelompok dengan rentang rata- terdiri dari tujuh genotip dan kelompok III terdiri rata kelompok antara 0,295 $\mathrm{cm}-0,405 \mathrm{~cm}$. dari delapan genotip (Tabel 3.). 


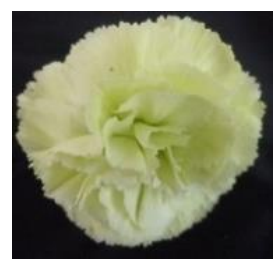

Pradorafit

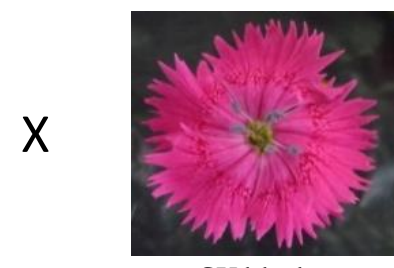

SK11_1
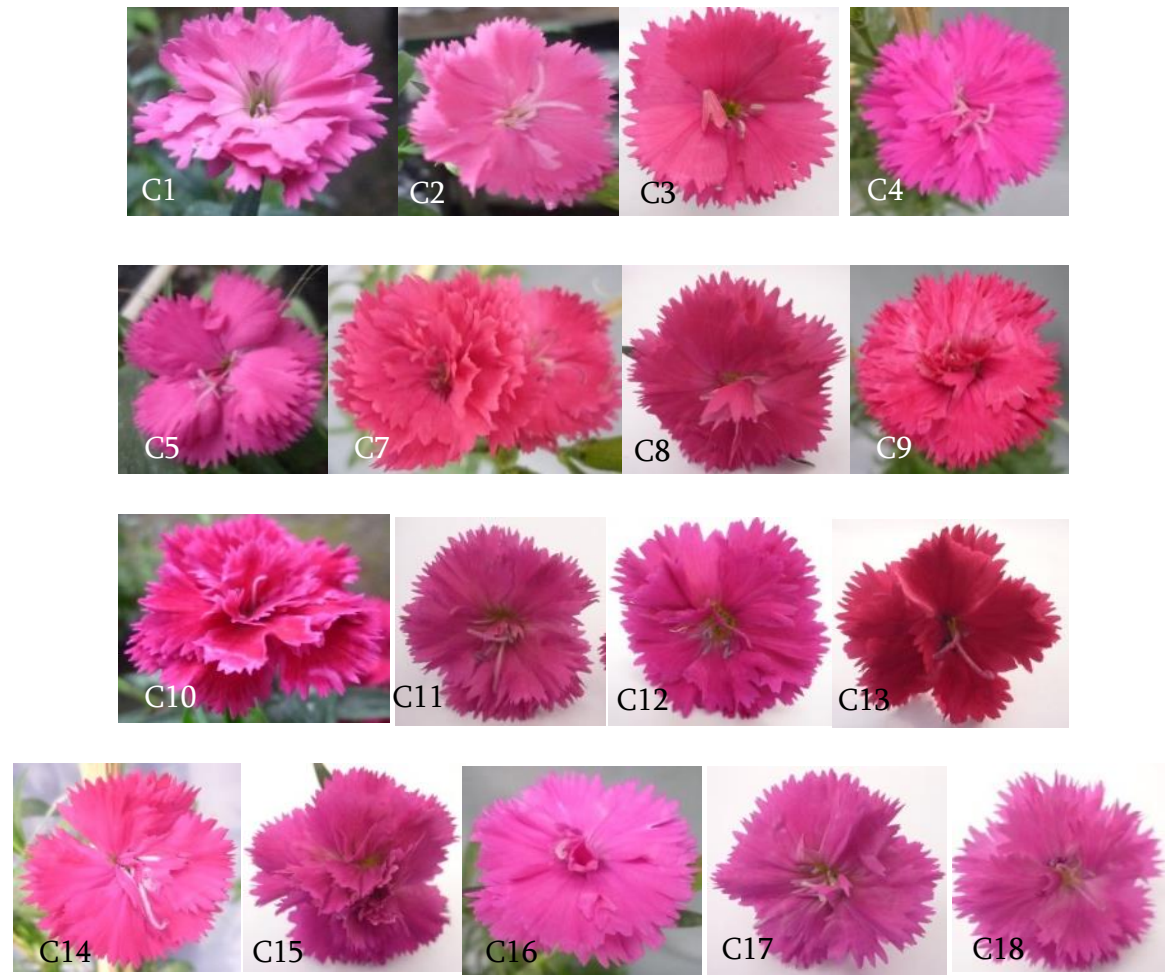

Gambar 1. Bunga 17 klon F1 populasi C.

Penampilan jumlah cabang 17 genotip populasi $\mathrm{C}$ terbagi menjadi tiga kelompok dengan rentang rata-rata kelompok antara $7,79 \mathrm{~cm}-12,59$ $\mathrm{cm}$. Kelompok I terdiri dari dua genotip, kelompok II terdiri dari dua genotip dan kelompok III terdiri dari 13 genotip.

Penampilan panjang daun terbagi menjadi tiga kelompok dengan rentang rata-rata kelompok antara $8,56 \mathrm{~cm}-13,16 \mathrm{~cm}$. Penampilan lebar daun populasi $\mathrm{C}$ terbagi menjadi empat kelompok dengan rentang rata-rata antara $1,22 \mathrm{~cm}-1,63 \mathrm{~cm}$.

Penampilan umur inisiasi berbunga populasi $\mathrm{C}$ terbagi menjadi empat kelompok dengan rentang rata-rata kelompok antara 51,43 hst $-82,68$ hst. Penampilan umur bunga mekar populasi $\mathrm{C}$ terbagi menjadi empat kelompok dengan rentang rata-rata kelompok antara $68,97 \mathrm{hst}-99,15 \mathrm{hst}$ (Tabel 4.)
Menurut Marwoto dkk. (1995) kecepatan pembungaan berhubungan dengan lamanya akumulasi fotosintat yang dibutuhkan untuk mengubah status fisiologi dari fase vegetatif ke fase generatif. Induksi pembungaan memerlukan ketersediaan energi yang cukup besar, dan setiap genotip memiliki kemampuan mengakumulasi fotosintat yang berbeda yang dipengaruhi oleh faktor genetik.

Penampilan diameter bunga populasi C tergabung dalam satu kelompok dengan rata-rata kelompok sebesar $3,95 \mathrm{~cm}$. Penampilan lama kesegaran bunga populasi $\mathrm{C}$ terbagi menjadi dua kelompok dengan rentang rata-rata kelompok antara 8,58 hari - 9,67 hari. Penampilan jumlah bunga mekar/waktu populasi C terbagi menjadi tiga kelompok dengan rentang rata-rata kelompok antara 2,89 kuntum $-5,55$ kuntum. 
Tabel 3. Hasil uji lanjut karakter tinggi tanaman, diameter batang, jumlah cabang, panjang dan lebar daun.

\begin{tabular}{|c|c|c|c|c|c|c|c|c|c|c|c|}
\hline \multirow{3}{*}{$\begin{array}{c}\text { No. } \\
1 .\end{array}$} & \multirow{3}{*}{$\frac{\text { Genotip }}{\text { C1 }}$} & & & & & & & & & \multicolumn{2}{|c|}{ Karakter } \\
\hline & & \multicolumn{2}{|c|}{$\mathrm{TT}$} & \multicolumn{2}{|c|}{$\mathrm{DBt}$} & \multicolumn{2}{|c|}{ JCab } & \multicolumn{2}{|c|}{ PDn } & \multicolumn{2}{|c|}{ LDn } \\
\hline & & 40,34 & c & 0,33 & $\mathrm{~b}$ & 5,75 & c & 10,21 & $\mathrm{~b}$ & 1,36 & $\mathrm{c}$ \\
\hline 2. & C2 & 49,53 & c & 0,33 & $b$ & 8,22 & c & 8,19 & c & 1,41 & c \\
\hline 3. & C3 & 52,80 & c & 0,30 & c & 8,62 & c & 9,30 & $\mathrm{~b}$ & 1,18 & d \\
\hline 4. & $\mathrm{C} 4$ & 49,19 & $\mathrm{c}$ & 0,33 & $\mathrm{~b}$ & 8,57 & c & 9,69 & $\mathrm{~b}$ & 1,23 & $\mathrm{~d}$ \\
\hline 5. & C5 & 44,64 & c & 0,34 & $\mathrm{~b}$ & 9,25 & c & 9,82 & $\mathrm{~b}$ & 1,28 & $\mathrm{~d}$ \\
\hline 6. & C7 & 59,64 & $b$ & 0,36 & $\mathrm{~b}$ & 7,26 & c & 9,46 & b & 1,51 & $\mathrm{~b}$ \\
\hline 7. & C8 & 46,32 & c & 0,27 & c & 8,12 & c & 13,16 & $\mathrm{a}$ & 1,24 & d \\
\hline 8. & $\mathrm{C} 9$ & 46,17 & c & 0,31 & c & 8,00 & c & 8,74 & c & 1,23 & d \\
\hline 9. & C10 & 49,16 & c & 0,40 & $\mathrm{a}$ & 10,07 & $b$ & 9,38 & $\mathrm{~b}$ & 1,41 & c \\
\hline 10. & C11 & 66,51 & $\mathrm{a}$ & 0,41 & $\mathrm{a}$ & 11,97 & $\mathrm{a}$ & 10,15 & $\mathrm{~b}$ & 1,46 & c \\
\hline 11. & C12 & 46,32 & c & 0,28 & c & 8,00 & c & 8,52 & c & 1,36 & c \\
\hline 12. & C13 & 59,61 & $\mathrm{~b}$ & 0,35 & $\mathrm{~b}$ & 13,20 & $\mathrm{a}$ & 8,65 & c & 1,46 & c \\
\hline 13. & C14 & 46,34 & c & 0,27 & c & 4,35 & c & 8,68 & c & 1,22 & $\mathrm{~d}$ \\
\hline 14. & C15 & 48,99 & c & 0,34 & b & 9,20 & c & 9,41 & $\mathrm{~b}$ & 1,24 & $d$ \\
\hline 15. & C16 & 43,22 & c & 0,29 & c & 9,85 & b & 9,60 & $\mathrm{~b}$ & 1,15 & $d$ \\
\hline 16. & C17 & 47,58 & c & 0,32 & c & 6,85 & c & 10,20 & b & 1,35 & c \\
\hline 17. & C18 & 44,50 & C & 0,32 & c & 9,07 & C & 9,46 & $\mathrm{~b}$ & 1,63 & $\mathrm{a}$ \\
\hline
\end{tabular}

Keterangan : Angka-angka yang diikuti huruf yang sama pada kolom yang sama tidak berbeda nyata berdasarkan uji Scott-Knott pada taraf 5\%. TT = tinggi tanaman, DBt = diameter batang, Jcab = jumlah cabang, $\mathrm{PDn}=$ panjang daun, LDn = lebar daun.

Tabel 4. Hasil uji lanjut karakter umur inisiasi bunga, umur bunga mekar, lama kesegaran bunga dan jumlah bunga mekar per satu waktu.

\begin{tabular}{|c|c|c|c|c|c|c|c|c|c|c|c|}
\hline \multirow{3}{*}{$\begin{array}{c}\text { No. } \\
1 .\end{array}$} & \multirow{3}{*}{$\frac{\text { Genotip }}{\text { C1 }}$} & \multicolumn{10}{|c|}{ Karakter } \\
\hline & & \multicolumn{2}{|c|}{ UIB } & \multicolumn{2}{|c|}{ UBM } & \multicolumn{2}{|c|}{$\mathrm{DB}$} & \multicolumn{2}{|c|}{ LKB } & \multicolumn{2}{|c|}{ JBMW } \\
\hline & & 85,15 & $\mathrm{a}$ & 102,80 & $\mathrm{a}$ & 3,84 & a & 9,25 & $\mathrm{a}$ & 3,45 & c \\
\hline 2. & C2 & 79,67 & $\mathrm{a}$ & 96,75 & $\mathrm{a}$ & 3,55 & $\mathrm{a}$ & 8,69 & $\mathrm{~b}$ & 2,73 & c \\
\hline 3. & C3 & 84,67 & $\mathrm{a}$ & 101,47 & a & 3,93 & $\mathrm{a}$ & 10,18 & a & 3,58 & c \\
\hline 4. & $\mathrm{C} 4$ & 73,25 & $\mathrm{~b}$ & 92,68 & $\mathrm{a}$ & 4,02 & a & 7,98 & $\mathrm{~b}$ & 3,35 & c \\
\hline 5. & C5 & 66,35 & $\mathrm{~b}$ & 84,50 & $b$ & 3,99 & $\mathrm{a}$ & 8,55 & $\mathrm{~b}$ & 4,40 & b \\
\hline 6. & $\mathrm{C} 7$ & 80,65 & $\mathrm{a}$ & 97,71 & $\mathrm{a}$ & 3,77 & $\mathrm{a}$ & 8,75 & $\mathrm{~b}$ & 4,29 & b \\
\hline 7. & $\mathrm{C} 8$ & 51,43 & $\mathrm{~d}$ & 68,97 & $\mathrm{~d}$ & 3,70 & $\mathrm{a}$ & 9,35 & a & 5,55 & a \\
\hline 8. & C9 & 72,15 & $\mathrm{~b}$ & 90,25 & $\mathrm{~b}$ & 3,93 & $\mathrm{a}$ & 8,95 & $\mathrm{~b}$ & 2,65 & c \\
\hline 9. & $\mathrm{C} 10$ & 85,73 & $\mathrm{a}$ & 103,11 & a & 3,95 & $\mathrm{a}$ & 9,89 & a & 4,00 & b \\
\hline 10. & C11 & 83,19 & $\mathrm{a}$ & 101,60 & $\mathrm{a}$ & 3,61 & $\mathrm{a}$ & 9,02 & $\mathrm{~b}$ & 2,87 & c \\
\hline 11. & $\mathrm{C} 12$ & 71,10 & $\mathrm{~b}$ & 88,90 & $\mathrm{~b}$ & 4,17 & $\mathrm{a}$ & 9,40 & a & 2,10 & c \\
\hline 12. & $\mathrm{C} 13$ & 83,55 & $\mathrm{a}$ & 99,25 & a & 4,17 & $\mathrm{a}$ & 8,25 & $\mathrm{~b}$ & 2,45 & c \\
\hline 13. & $\mathrm{C} 14$ & 70,90 & $\mathrm{~b}$ & 87,60 & $\mathrm{~b}$ & 4,46 & $\mathrm{a}$ & 8,50 & $\mathrm{~b}$ & 2,60 & c \\
\hline 14. & C15 & 71,60 & $\mathrm{~b}$ & 90,20 & b & 3,76 & a & 9,55 & a & 3,00 & c \\
\hline 15. & C16 & 60,57 & $\mathrm{~b}$ & 82,10 & $\mathrm{~b}$ & 3,88 & $\mathrm{a}$ & 10,00 & $\mathrm{a}$ & 2,50 & c \\
\hline 16. & C17 & 62,00 & c & 79,00 & c & 4,09 & $\mathrm{a}$ & 9,55 & $\mathrm{a}$ & 3,10 & c \\
\hline 17. & C18 & 78,86 & $\mathrm{a}$ & 97,00 & $\mathrm{a}$ & 4,31 & $\mathrm{a}$ & 9,83 & a & 3,15 & c \\
\hline
\end{tabular}

Keterangan : Angka-angka yang diikuti huruf yang sama pada kolom yang sama tidak berbeda nyata berdasarkan uji Scott-Knott pada taraf 5\%. UIB = umur inisiasi berbunga, UBM = umur bunga mekar, $\quad$ DB = diameter bunga, LKB = lama kesegaran bunga, JBMW = jumlah bunga mekar per satu waktu. 
Karakter lama kesegaran bunga adalah salah satu karakter yang menentukan nilai ekonomi tanaman hias tersebut. Variasi lama kesegaran bunga antar genotipe berhubungan dengan variasi akumulasi karbohidrat sejak genotip tersebut mampu menghasilkan daun berlebih (Mehmood et al., 2014). Daun adalah unit fungsional penting untuk fotosintesis yang berpengaruh besar terhadap pertumbuhan dan hasil bunga bagi beberapa tanaman. Jumlah daun berlebih dengan kandungan klorofil tinggi meningkatkan fotosintesis dan karbohidrat. Karbohidrat merupakan sumber energi untuk menumbuhkan pentul bunga, bunga mekar dan ketahanan kesegaran bunga (Tarannum \& Naik, 2014).

Sebagian besar genotip populasi C memiliki kombinasi karakter yang sesuai untuk dijadikan anyelir pot, yaitu tanaman pendek, diameter batang besar, jumlah cabang banyak, genjah, bunga mampu bertahan lama dan jumlah bunga mekar pada satu waktu banyak. Genotip C5, C8, C9, C12 cocok dijadikan anyelir tipe pot. Genotip C10 memiliki banyak karakter unggul sebagai tanaman hias pot, karakter bunga dengan dua warna bunga pada satu petal merupakan keunggulan dibandingkan genotip lainnya. Menurut Qud et al. (1995) dalam Nurmalinda et al. (2011), pada komoditas tanaman hias, warna bunga merupakan kontributor utama terhadap nilai ekonomi bunga.

\section{KESIMPULAN}

1. Semua karakter terukur yang diamat menunjukkan perbedaan nyata antar hibrid $\mathrm{F}_{1}$.

2. Sebagian besar genotip populasi $\mathrm{C}$ memiliki karakter yang sesuai dengan karakter anyelir tipe pot, yaitu tanaman pendek, diameter batang besar, jumlah cabang banyak, genjah, bunga bertahan lama dan jumlah bunga mekar/waktu banyak.

3. Genotip C5, C8, C9, C10 dan C12 potensial dijadikan anyelir tipe pot.

\section{UCAPAN TERIMAKASIH}

Ucapan terima kasih disampaikan kepeda Badan Penelitian dan Pengembangan Pertanian, Kementerian Pertanian yang telah membiayai penelitian ini.

\section{DAFTAR PUSTAKA}

Demmink, JF. 1978. Interspesific crosses in carnation In Quagliotti, L. and A. Balldi (Eds.). Genetic and Breeding of Carnation and Gerbera. Institute of Plant Breeding and Seed Production. Turin, Italy. 289 p.

Hardjoko, B. 1999. Anyelir dalam Supari Dh. (Ed.) Seri Praktek Ciputri Hijau : Tuntunan Membangun Agribisnis. PT. Elex Media Komputindo. Jakarta. p. 219-234.

Indriyani, I dan S Sumartini. 2012. Pengaruh Kerapatan Bulu Daun dan Kelenjar Gosipol terhadap Infestasi Hama Pengisap Daun Amrasca biguttula Ishida dan Penggerek Buah Helicoverpa armigera Hubner pada Kapas. Jurnal Littri 18 (3) : 95 - 101.

Jawaharlal, M, M Ganga, K Padmadevi, V Jegadeeswari and S Karthikeyan. 2010. A Technical Guide on Carnation. Department of Floriculture and Landscaping, Horticultural College and Research Institute. Tamil Nadu Agricultural University, Coimbatore.

Kato, J, H Ohashi, M Ikeda, N Fujii, R Ishikawa, H Horaguchi, J Amano, M Hayashi, and $\mathrm{M}$ Mii. 2008. Unreduced gametes are the major causal factor for the production of polyploid interspecific hybrids in Primula. Plant Biotechnology 25 : 521 - 528

Marwoto, B, T Sutater, S Lia, dan E Setyawati. 1995. Characterization and selection of Chrysanthemum result crosses of selected cultivars. Progres Report I. Program Biobrees. Balai Penelitian Tanaman Hias. Jakarta.

Mehmood, MA, MSA Khan and N Ahmad. 2014. Growth, yield and quality (Dianthus caryophyllus L.) cultivars under lath house conditions. Journal of Ornamental Plants 4 (1) : $27-32$.

Mii, M, M Buiatti dan F Gimelli. 1990. Carnation In PV Ammirato, DR Evans, WR Sharp dan YPS Bajaj (Eds.). Handbook of Plant Cell Culture, Volume 5, Ornamental Species. McGraw-Hill, Inc. The United States of America. p. 284 - 318

Nurmalinda, S Kartikaningrum, NQ Hayati dan D Widyastoety. 2011. Preferensi konsumen terhadap anggrek Phalaenopsis, Vanda dan Dendrobium. J. Hort. 21 (4) : 372 - 384.

Office of The Gene Technology Regulator. 2015. The Biology of Dianthus caryophyllus L. 
(Carnation). Department of Health \& Ageing. Australian Government. 27 p.

Tarannum, MS and BH Naik. 2014. Performance of carnation (Dianthus caryophyllus L.) genotypes for qualitative and quantitative parameters to assess genetic variability among genotypes. American International Journal of Research in Pormal, Applied and Natural Sciences 5 (1) : $96-101$. 